\title{
NO ETHICS WITHOUT THINGS
}

\author{
Kenneth M. George
}

\begin{abstract}
Just as recognition and pursuit of the human good take place in language and action, so too do they unfold in encounter with the material and visual. The ethical crises, projects, and striving we see in everyday religious life are worked out not just in the intersubjective play and politics of language but also in encounter with, in dwelling with, material and visual substances and forms. This essay considers the material conditions that make possible the "ethical pleasures" sought by Indonesian painter A. D. Pirous in making and displaying contemporary works of "Islamic art," most especially works that make "visual recitation" of passages from the Qur'an.
\end{abstract}

KEY WORDS: anthropology of art, anthropology of ethics, material culture, Islam, A. D. Pirous, Indonesia

To live together in the world means essentially that a world of things is between those who have it in common.

-Hannah Arendt, The Human Condition (1958, 52)

\section{Prefatory Remarks}

Roughly twenty-five years ago, I began an ethnographic collaboration with Indonesian painter Abdul Djalil Pirous (b. 1933, Meulaboh, Aceh) in order to explore the cultural politics of "contemporary Islamic art" in Southeast Asia. That collaboration continues until today. For many years, my focus was on the political and cultural forces that had summoned Pirous forward as an artist-citizen in Indonesia as that newly independent country came onto the world stage. In time, those forces led him to look to Islam afresh and see in it powerful aesthetic and ethical possibilities. My book, Picturing Islam: Art and Ethics in a Muslim Lifeworld (George 2010), tells the story of how Pirous took up the venture of making "Islamic art" amid the currents of national and global communication. It

Kenneth M. George is Professor of Anthropology and Director, School of Culture, History and Language in the ANU College of Asia and the Pacific, at the Australian National University. His books include Picturing Islam: Art and Ethics in a Muslim Lifeworld (WileyBlackwell, 2010), Showing Signs of Violence: The Cultural Politics of a Twentieth-Century Headhunting Ritual (University of California Press, 1996), and Spirited Politics: Religion and Public Life in Contemporary Southeast Asia (Cornell SEAP, 2005), co-edited with Andrew Willford. Kenneth M. George, ken.george@anu.edu.au. 
1 is about him finding cultural, political, and ethical location as a postcolonial Muslim artist.

Pirous was no stranger to me. We had been friends since 1985, and from the start of our project, he has encouraged me to develop a feel for his paintings, and to learn from them. "Good paintings," he once said to me, "are always full of surprises." Paintings thus call on us to be receptive to them. What possibilities do they disclose to us? How might they change our sensibilities? What might they show us about dwelling in the world? What predicaments do they pose? These, I think, are questions that belong to the field of "visual ethics" or that will help us conjure it as a fruitful category for reflection and study.

"Visual ethics" is not a term that I used in Picturing Islam, but served as a rubric for a symposium about the book, visual culture, and religious ethics at the 2011 annual meeting of the American Academy of Religion. My treatment of ethics in the book stemmed in part from my reading of work by Judith Butler (2005), Michel Foucault (1997, 2005), and Paul Ricoeur (1992), and offered at best a glancing consideration of "Islamic ethics" or religious ethics, more generally. More crucially, I drew from my friendship and conversations with Pirous to reflect on the ethical dispositions that led him to make abstract paintings featuring Qur'anic verse. For Pirous, making these works has been an ethical venture in several respects: It has to do with fashioning an "expressing self" in relationship with others; with being useful, and showing goodness and responsibility toward others in everyday conduct (ihsan); with cultivating Islamic values and dispositions found in in the Qur'an; and with giving himself and others something he calls "ethical pleasure" (about which, more below). In this light, the ethical-in its various modalities-may be found in the content of a painting (Qur'anic verse); in the relationship between the artist and his audience as mediated by a painting; and in the artist's effort to align his art and the way that he has lived with God's will.

My aim as an ethnographer and friend in that project was to grasp the understandings and ideals guiding Pirous's work-a task we might call descriptive ethics. It was not my goal to suggest a normative or prescriptive framework for ethics in the making of art, nor was it to critically interrogate "Islamic ethics." In this essay, I would like to push on to ground that is new for me-understanding some of the material and visual conditions for ethical life, especially as they may be manifest in works of art. Pirous and some of my other Indonesian friends use the word penghayatan to talk about their commitment to life and life forms. The word suggests to me an ethics of recognition and receptivity, not just to people around us, but aimed toward and engaged with the objects and images that suffuse our world. As we draft our ideas about or for a "visual ethics," we may wish to acknowledge how ethics rests upon our material and visual condition. 


\section{Ethics, Language, and Things in Everyday Life}

In his introductory essay to Ordinary Ethics: Anthropology, Language, and Action, Michael Lambek reminds us that ethics is intrinsic to everyday speech and activity, and forms an ineluctable part of the human condition (Lambek 2010a, 1; see also Lambek 2010b, 39, 42, 61-63). As Veena Das puts it elsewhere in that same volume, "Everyday life is the site in which the life of the other is engaged" (Das 2010, 376). Although both Lambek and Das point to the embeddedness of ethics in everyday life, they differ in some degree about what we might call the visibility of ordinary ethical sensibilities. Lambek stresses the tacit quality of ordinary ethics, the way ethics goes unremarked and "without calling undue attention to itself" in the foundations of the everyday (2010a, 2). Ethics is more readily discernible, he says: "(1) in respect to its breaches; (2) with regard to ethical problems or issues in which the right thing to do is unknown or hotly contested; (3) in prophetic movements of social and ethical renewal; and (4) among priestly classes attempting to rationalize and educate" (Lambek 2010a, 2). Moments of failure, conflict, religious instruction, or social renewal-however ordinary those moments might be-bring ethics into view. Das, by way of contrast, thinks of everyday life as a site of ethical striving, a site where uncertainty, rather than agreed-upon virtues or ideas of the common good, is basic to ethical sensibilities and projects that achieve or arrive at a newness, at a "coming into being" (Das 2010, 376-78, 396-97). What I take away from Das is that ordinary ethics is not just about the taken-for-granted foundations for the everyday here and now (per Lambek), but also about perseverance, "nextness," and possibilities for the "otherwise" (compare Kompridis 2006; Povinelli 2011). Ethics, among other things, is about disclosure and bringing life possibilities into view.

I did not have the essays by Lambek and Das at hand when I was writing Picturing Islam, but recruit them here to take some first steps in answering-or perhaps merely echoing - the question I pose at the end of that book: "Will we see ethics differently if we look to pictures as the fulcrum of ethical relationships?" (George 2010, 145). As I suggested in my prefatory remarks, my question was prompted by my friendship and ethnographic collaboration with Pirous, and his desire to bring his art into accord with his understanding and experience of Islam-a form of ethical labor in which Pirous sought congruence between his art and the way that he lived. Pirous's own ideas about the ethical aspects of his work do not exhaust all those ethical dimensions worthy of ethnographic or philosophical concern. What I cannot stress enough is how his ethical venture also and unavoidably involves material things, specifically, the paintings and prints he has made. A material world does not figure strongly in the conceptualizations of "ordinary ethics" put forward by 
1 Lambek, Das, or the other co-contributors to Lambek's volume. Their emphasis on language and action largely overlooks how ethics may be tethered to things and thinginess. Things, of course, are quite ordinary-our everyday worlds are suffused with them, as Hannah Arendt noted in The Human Condition (1958)—and I would argue that we cannot have a sufficient account of ordinary ethics until we admit materiality into our reckonings. ${ }^{1}$

A similar case ought to be made for the place of the visual, or visual culture, in our depiction and study of everyday ethics. In her introduction to this focus issue, Elizabeth Bucar reminds us that the visual is fundamental to human experience. We are, she says, "visualizing, picturing, and seeing creatures" (2016, xx). It is not just things that suffuse our world, but images and visual culture more broadly. ${ }^{2}$ Indeed, "to live in any culture whatsoever," writes W. J. T. Mitchell, "is to live in a visual culture" (2005, 349). No society, no religion, is without visual culture, and so we should expect everyday ethics and ethical life to be caught up in the visual, no less than they are caught up in language and action, the realm of human practice of central concern in Ordinary Ethics.

Just as recognition and pursuit of the human good take place in language and action, so to do they unfold in encounter with the material and visual. Ethical crises and projects of the sort mentioned by Lambek, and the vulnerability and ethical striving so thoughtfully explored by Das, are worked out not just in the intersubjective play and politics of language but also in encounter with, in dwelling with, material and visual substances and forms. ${ }^{3}$ This suggests to me that we must acknowledge that our reflexivity, our conscience, and our pursuit of the good depend upon the material and the visual no less than they do upon speech. Conscience may be experienced and understood as an internal voice that summons us to this or that path of action (see, for example, Simmel 1950, 254). Yet we should ask: Must conscience be imagined (and sequestered) as inner speech only? ${ }^{4}$ Might our conscience also turn on the look of images or the touch of things, our being drawn to things? Might conscience not also find external expression and intelligibility in our relationship with the

\footnotetext{
${ }^{1}$ Among the co-contributors to Lambek's volume, Webb Keane has been pioneering the study of materiality, agency, and religion. His chapter in that volume directs attention to the objective materials of semiotic forms (Keane 2010, 78), and so suggests ways for scholars to bring the materiality of things and the objectified forms of language together in a sweeping theoretical approach to ethics.

${ }^{2}$ See Pinney 2006 for a splendid review of approaches to the problem of the visual.

${ }^{3}$ See, for example, my essay on lifewriting and art works for an exploration of ethics, conscience, and their intermingling with verbal and material forms (George 2012b).

${ }^{4}$ Compare, for example, how Indonesian-borrowing from Arabic-renders conscience as hati nurani, the "luminous, enlightened heart," or as a "heart so enlightened that it may see what is invisible to the eyes."
} 
material and visual world? Might conscience also incline us to see, or look in particular ways? Could it be that the objects and images around us give us ethical direction? Or make us vulnerable?

The thinginess of visual culture and the visuality of material culture feature prominently in the work of David Morgan (1998, 2005, 2008, 2010), who places emphasis on the way objects and images mediate religious belief, practice, and experience, especially with respect to feeling and bodily sensation. Morgan's work is part of a groundswell of interest in the fields of anthropology and religious studies about materiality. ${ }^{5}$ (Even a partial account of that groundswell goes well beyond the scope of this essay.) Signal studies in the "material turn" commonly take up problems of subjectivity, agency, power, circulation, affect, and the mediation of ideas and experience. Although these studies seldom put explicit

14 15 or sustained focus on ethics, we may nonetheless plumb them for ways to relate the material to the ethical.

\section{On "Bundling" and the "Stickiness" of Things}

Among the prominent voices in the "material turn," Webb Keane has argued that "materiality is the precondition for the social circulation and temporal persistence of [religious] experiences and ideas" (2008, 230), and a precondition for "ethical consciousness" $(2010,78)$. Of special benefit to me is his notion of "bundling" (Keane 2006, 200-1; 2008, 230) - the ways in which material things combine an indefinite number of properties and qualities that in turn give things an inherently open-ended and vulnerable character. ${ }^{6}$ Keane uses examples in which the flammability of a thing's constituent materials-the cloth of a flag, the wood of a venerated Chinese ancestral tablet-make the thing in question vulnerable to contempt and desecration: a flag is burnt in protest, a tablet is used as cooking fuel. What interests me here is that Keane has helped explicate why an ordinary ethics - or the ordinary ethics we call religious ethicscommonly take the vulnerability of things as a source of concern. The bundled properties of an object introduce contingencies that might subvert or derail its purpose or intended use. By the same token, the vulnerability and open-endedness which material bundling makes possible

\footnotetext{
${ }^{5}$ Morgan views visual culture studies as a subfield of material culture (2008, 229).

6 "Bundling" is also key to the workings of D. W. Winnicott's "transitional objects" (1971) - the fuzziness and warmth of a blanket or teddy bear are a common example. The material properties of the transitional object "gives the child an experience of a meaningful connection within their inner world with an object that is recognized as being, in some sense, not them and offers an early experience of a form of subjectivity beyond the self" (Lynch 2010, 46).
} 
1 leave room for reflexive disclosure, surprise, and a change of sensibilities among those who dwell with the thing.

While a thing is, in part, a bundling of properties that inhere in it, a thing is also, as Sara Ahmed would say, "sticky"-"what it picks up on its surface 'shows' where it has traveled and what it has come into contact with" $(2006,40)$. Things take shape, arrive before us, and come into reach through labor, encounter, and the way we turn toward them. No less sticky is the affect that turns us toward things, and that brings us into intimate contact with them. Describing the stickiness of happiness, Ahmed observes how happiness not only attaches to a thing and brings it near, but also "sticks" to whatever is around the object, including the conditions under which the thing took shape and appeared within our lifeworld (2010, 32-33). Things-happy things, Ahmed calls them-carry the promise of happiness; happiness is presumed to follow or be sent forth from the object. It is as though happiness is in the aim of a thing. "We arrive at some things because they point us toward happiness," writes Ahmed (2010, 40). "When we feel pleasure from such objects," she says, "we are aligned; we are facing the right way" (2010, 37).

Were I to rewrite Picturing Islam as a bolder summons to the study of "visual ethics," I might begin by saying that there is no ethics without things, rather than ending the book, as I did, asking if pictures matter to ethical life. Without forsaking an ethnographic and analytic grasp of the cultural and political forces that so deeply etched Pirous's lifeworld and ethico-aesthetic sensibilities-Islam, nationalism, modernism, globalization, and authoritarian rule to name some of the key ones-I might include an appreciation for material "bundling" and "stickiness" to help make me more receptive to my friend's strivings, and to the ethical problems and debates he has had to confront as a Muslim artist-citizen in postcolonial Indonesia. And too, I might engage more probingly than I did in Picturing Islam with Pirous's interest in "ethical pleasure." Neither Pirous nor I think of ethical pleasure as an "Islamic principle," but I think he might agree with me in thinking of ethical pleasure as an artifact of a contemporary practical Islam that informs Muslim lifeworlds and Muslim encounters with works of art. A more sustained look, then, into ethical pleasure as I came to learn about it in the company of an Indonesian painter might guide us toward a richer, more pluralistic understanding of visual ethics and its material entailments and predicaments.

\section{4. "Ethical Pleasures" and the Work of Religious Art}

One of the reasons I want to dwell on ethical pleasure is my conviction that we should call into question popular views that expect Muslims everywhere around the globe to adhere to a uniform ethico-aesthetic sensibility mandated by a pleasureless, inflexible, and iconoclastic religious 
1 creed (George 2009, 2012a). We need to turn our scholarship against universalist notions of a timeless "Islamic aesthetics" to discover the everchanging ways that art has mingled with religion and ethics in Muslim communities (compare Flood 2002). More important for the discussion here is how Pirous's ideas about ethical pleasure came to orient his artistic and religious strivings even as these threw him into religious debates about the ethics of making art. Bundling and stickiness played a part in the aims and predicaments of this venture-indeed, in the very feel of pleasure-and so may demonstrate some of the ways visual ethics involves material and affective dimensions and not simply visual ones.

"Ethical pleasure" first came up in my conversations with Pirous as we discussed a series of turning points in his work in the early 1970s after he had established himself as a rising star in the Indonesian art scene. Up until that time, Pirous worked without any interest in Islamic themes or iconographies; abstraction, spontaneity, and self-expression were his driving visual pursuits. A visit to the standing collection of Islamic art at the New York Metropolitan Museum of Art in the winter 8 of 1970 changed all that. Looking at the objects on display-calligra9 phies, manuscripts, ceramics, and fabrics-and finding in them a simi20 larity to the everyday arts of his childhood in his ethnic homeland in 21 Aceh, Pirous was overcome by a visceral and wholly unexpected thrill of 22 recognition. Returning to the studio after that moment of recognition 23 and surprise, Pirous began a life-and-art-changing painterly exploration of iconographies that would convey his ethno-religious belonging and that would distinguish him as an "authentic" Indonesian artist, rather than as a Third World abstractionist working in imitation of modernist styles associated with Europe and the United States. This new direction in his work also coincided with his first experimentations with acrylic paints, and with his two-year training in graphic arts at the Rochester Institute of Technology. The feel of new material (acrylics do not behave the way oils do), the textured, antique look of inked plates, and the discipline needed for graphic work coincided with a new expressive vision aimed at capturing ethno-religious sensibilities in his art.

Paintings in his solo show in Jakarta in 1972 and in the 1974 Indonesian Biennale featured what he calls "expressive calligraphy" (kaligrafi ekspresif) worked up in oils, acrylics, and modeling paste. The paintings displayed disfigured "Arabic" letters on what looked to be surfaces weathered by time. Some of the paintings included legible Arabic characters put together randomly and with the purpose of thwarting viewers from reading beyond the figure of the character. In other works, the letters were deformed beyond legibility but still kept some resemblance to

F1 42 Arabic, as in White Writing (Figure 1). Pirous explained to me that he 43 was not interested in content, but in the expressive potential of calligra44 phy as a pictorial form: 


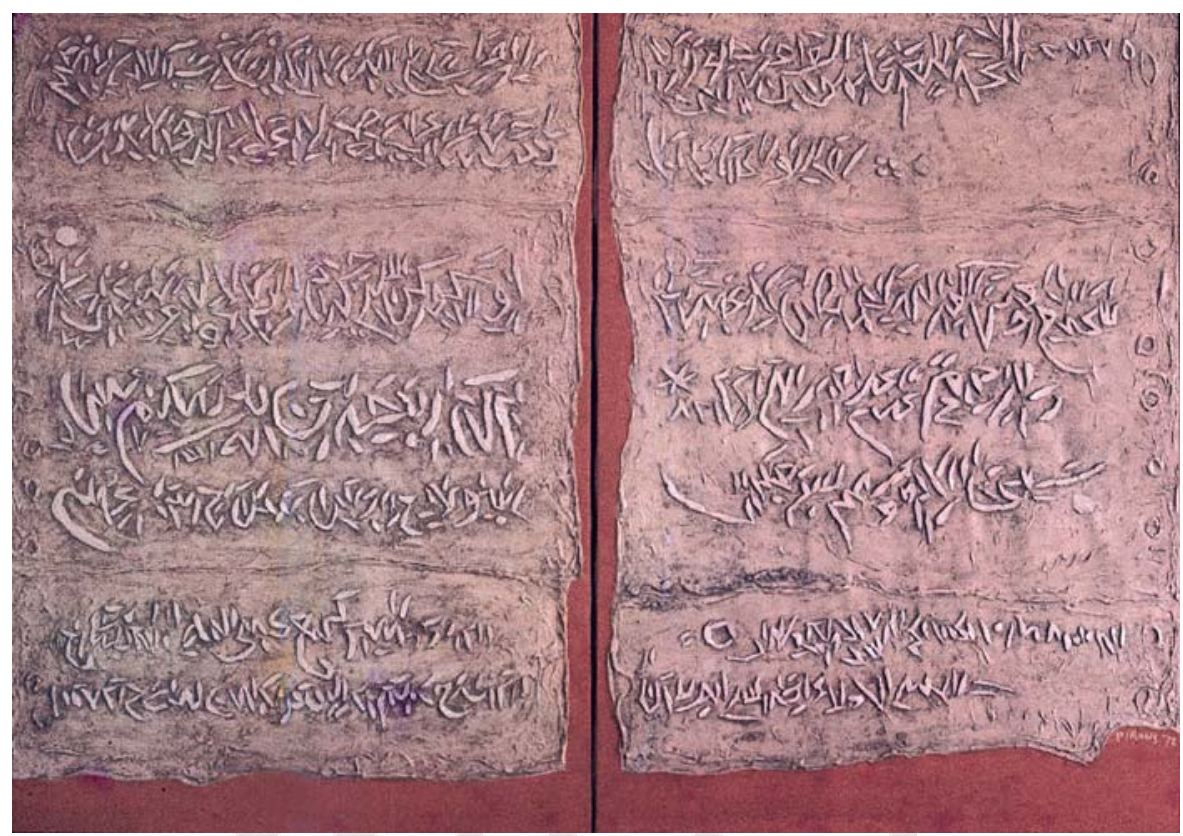

FIGURE 1. White Writing. A. D. Pirous. $1972.100 \times 180 \mathrm{~cm}$, marble paste, acrylic on canvas. Courtesy of the artist and Yayasan Serambi Pirous.

I did not want to be held back by the dynamic of calligraphic writing, or the form of calligraphy because I still reckoned that it inevitably would be read. But I could be free if I just painted characters by themselves. Some were curved, some upright, some to the left, some to the right, with periods, inside of curves that were very expressive. That gave me more freedom, and also gave me a kind of satisfaction in the dynamic of the lines themselves. I didn't feel it necessary to keep it so that the writing could be read. It was very clear that they came from Arabic. There clearly were $h a$, $k a, l a, m i m$, and so on. But I didn't feel it necessary to combine them into a sentence. I was building an atmosphere, an atmosphere. I also sensed that atmosphere in the Qur'an, how a sura came into being, how a sura was brought down as wahyu, divine revelation. With Arabic writing, we have a specific icon, a specific world, something spiritual, meditative, and contemplative. I took this up with the idea of not being wrapped up in the word, but rather, of being wrapped up in the unexpressed word. I didn't want to say anything, but wanted to create a certain feeling, an expressiveness.

Here, I think, is a good example of Pirous at play with the stickiness of material things. These "expressive" calligraphic forms were recognizably "Arabic." "Sticking" to them was the whole of Qur'anic revelation; an orthography that brought believers closer to Allah (see George 2009). He does not say so, but my long friendship with Pirous persuades me 
1 that he felt a pleasure in aligning or directing his self-expression to an ambience of divine revelation, to awareness of God's care and closeness. The venture, the pleasure, felt "right" or "rightly guided." Or perhaps I should say there was pleasure, a happiness, in being "rightly guided," in being close to God.

We may have hints of this pleasure in the physical composition of the paintings themselves. The expressive calligraphic orthography and calligraphic objects (plaques, tombstones, and fragments of manuscripts) were built up in modeling paste on expanses of base canvas painted in acrylic monocolor. The calligraphy and calligraphic objects occupy the front-most visual plane of the work, and show the touch of the artist's hand. The monocolor acrylic field, by way of contrast, almost lacks the signs of expressive painterly touch in the manner of color field painting, and so frees the color from representational tasks. Some of the paintings' titles-White Writing, Red Writing, and Blue Calligraphy, for examplesuggest ways that color and its light supply spiritual and visual moods 7 for presentation or disclosure of the expressive calligraphic forms, as 8 though each was a color of divine revelation and magnificence. The immersive experience of bringing calligraphic forms into being in a bath of color and light perhaps made the creative work, the creative labor, seem like revelation itself. There is, too, a striving here to draw the viewer into the happiness and revelation disclosed by the painting.

The problematic "legibility" of these forms opened the artist up to criticism. As I have explored elsewhere (George 2009), many Muslims, and Muslim clerics in particular, feel a custodial ethic toward the Qur'an regarding its recitation, its visual-material reproduction as a text, its safekeeping, and its handling as a textual object. "Expressive calligraphy" seemed to some Indonesian clerics who attended the shows a wrongly pursued deformation of divine orthography; it was "incorrect" in light of a Qur'anic standard, and theologically suspect. One should not play with divine inscription. For others, the effect of looking upon images of something that was "written" and "Arabic," and yet unreadable was disturbing. Responses like these propelled Pirous away from self-expression and selfabsorption toward greater restraint and ethical concern:

When I exhibited, people began to talk. "What are you writing? What are you saying?" "Oh, this painting is very close to the treasure of Islam!" "If this is Arabic writing, maybe this is Sura Al-Fatihah (Q. 1, The Prologue) and this is Sura Al-Falaq (Q. 113, The Rising Day)." I thought about it a long time. Those comments pushed me into thinking about art and message. In the beginning, the aesthetic in my works of art didn't know compromise with meaning. Through the visual someone could feel meaning within the abstraction. But think how happy people would be, think about their sense of belonging to works of art like this-the aim of which is to approach Islamic concerns-think how much fuller it would be, if they 
could look and read, "Oh, this statement is about Sura Al-Ikhlas (Q. 112, Pure Faith)" and so forth. I said to myself, "If I do Sura Al-Ikhlas the way it is bound together in the Qur'an, it will restrict me in a way that will be extremely awkward for my expressive work." I saw this as a limit that I didn't want. And then suddenly I woke up. Me, what is my life all about? What is a good person? A good person is someone who is useful to others. If I give them something they want, I will be useful. And so I decided to be useful. This is the concept of khairuqum an-fa'aqum linnas-a person useful to others. So I sacrificed myself, putting a limit on my free expression, but I came back to values that I could explore more frequently and more meaningfully in the Qur'an. I planted in the paintings concepts and philosophical values that would make them more enjoyable. Aesthetic pleasure and ethical pleasure together.

The paintings in these shows thus occasioned criticism that prompted Pirous to reflect on his own aspirations and artistic subjectivity while seeking receptivity and acceptance from gallery-goers. They occasioned exercises in painterly conscience-in the sense of a "knowing through dwelling with." Being useful to others through paintings comported well with his conscience, with his pursuit of ihsan-the idea and aim of showing one's goodness and responsibility to others. At the same time, the paintings offered material mediation and extension of his conscience at work.

His first calculated step toward being useful to others was to make the calligraphy in his paintings legible, always using the written figures to quote (to "visually recite," I like to say) Qur'anic verse, or Jawi "translations" of Qur'anic verse. "Jawi" is the term for MalayIndonesian when written in Arabic orthography.) Let me use one of my favorites from Pirous's many Qur'anic works, For the Sparkling Morning Light (Figure 2). The cracked, magenta tablet in the center of the painting displays a verse from Q. 93 Ad-Duha ("The Early Hours of Morning") in Qur'anic Arabic and turquoise. ${ }^{7}$ The first few ayat reassure the faithful in the face of adversity:

In the Name of God the Compassionate the Caring

By the morning's bright light

By the night when it is still

Your Lord has not abandoned you and does not hate you

What comes after will be better for you than what came before. (Q. 93: 1-4)

The painted sura goes on to admonish believer-viewers to keep recounting Allah's many favors and blessings.

7 "Pirous" (pirus) is the Arabic, Persian, and Indonesian-Malay word for turquoise. Thus there is in the painting a "sticky bundling" of signifying color (turquoise), a name, painterly calligraphic touch, and visual recitation of Qur'anic message in divine orthography. 


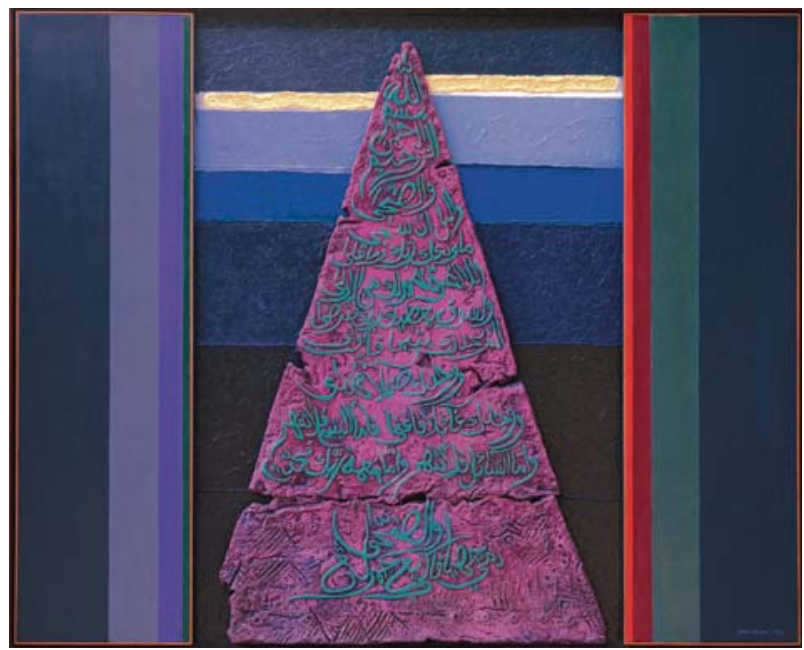

FIGURE 2. For the Sparkling Morning Light. A. D. Pirous. 1982. $160 \times 200 \mathrm{~cm}$, fiberglass, gold leaf, acrylic on panel and canvas. Courtesy of the artist and Yayasan Serambi Pirous.

The doubling of pleasure in the disclosure of a painting no doubt goes beyond what Pirous conveyed to me. But we might begin with his account of ethical pleasure and the way he contrasts it with aesthetic pleasure. Pirous seems to suggest that ethical pleasure derives from the material recitation of Qur'anic verse in anticipation of its being recognized and read (or recited) by others. He did not attribute an ethics to the "aesthetic pleasure" in viewing a painting. Ethics, in his view, involves time and reflection in the way that taking in a painting does not. As he once remarked to me, "You know, you grasp a painting as a whole. In a single moment you either like it or you don't. It doesn't need time. But for the verse here, you need time for that, for reflection. That's why I say there is aesthetic pleasure and ethical fulfillment in my paintings." Ethics arises from reading and spiritual reflection (tafakkur) on Qur'anic verse. In Pirous's account, ethics is about giving religious or spiritual content to a painting, and has little to do with the aim or pleasures of artistic form. Ethical pleasure, in this framework, is about aligning oneself with, and taking pleasure in, Qur'anic recitation and reflection. Indeed, Pirous has often talked about his paintings as spiritual notes (catatan spiritual) aimed at cultivation of self and inner being (batin). The paintings aim for happiness and contentment, even as they disclose or point to the happiness that is the Qur'an (the recitation of the divine message).

Here I should confess that I sometimes saw the Qur'anic calligraphy as a source of austerity, didacticism, and constraint, rather than as a form sticky with joy or awe. So did others. The didactic intent (and content) in Pirous's Qur'anic paintings led some to see the venture not so much as "art" but as da'wah-the preaching of Islam, a matter that in the minds 
of many should be left to religious authorities, not painters (see George 2009). Pirous, in this perspective, could be charged with usurping the role of Islamic authorities. Pirous routinely had to fend off such charges for years, and consistently denied interest in practicing da'wah through his paintings. There were worldly cultural, political, and religious circumstances that Pirous had to contend with to be sure, and these may have inclined him to dissociate his work from da'wah. Alienating the ulama or the ummah more generally surely had its risks. Indeed, saying as he often did, "These paintings are just my spiritual notes," might have been intended to reassure others than he did not have usurping ambitions. At the same time, the ethical gesture most inherent in dawah is that of summons or invitation to others, a gentle beckoning to the faith. As I look at things now, that gentle summons to others lends itself importantly to the ethical pleasure of his paintings. It is as if he is saying, "Join in this happiness, this mindfulness of God (dzikir)."

What I have long overlooked by putting undue weight on the way Pirous would contrast aesthetic and ethical pleasure is the way he was always talking about bundling them in his art. Not only a doubled pleasure, but a "sticky bundling" of divine revelation with the play of painterly materials and vision. This bundling did not have happy or uniform effects for all. Clerics would occasionally object that this was no way to handle Qur'anic verse. As the Indonesian Minister for Religious Affairs bellowed to the press in 1992, "The Qur'an should not be sacrificed for art!" It was not just religious authorities who were disturbed by the bundling. One of Pirous's colleagues in the Indonesian art scene complained, "Why are you ruining these paintings with this writing?"-a remark that stubbornly refused to acknowledge the Qur'anic verse as anything more than a formal graphic presence that disturbed or marred painterly vision. Still another artist accused Pirous of "selling" the Qur'an by featuring it in work that could be bought and sold.

We hear in these objections and complaints concern about a normative ethics for the material interpenetration or bundling of art and faith. This is not an issue of categories alone-that is, what counts for art and what counts for religion-but goes to the ethics of handling sticky, bundled materials. ${ }^{8}$ Does handling a Qur'anic painting require ablutions (wudu) on the part of Muslims? Do the sensory effects of the painting that emanate from color, form and so on, overpower the Qur'anic verse in visual recitation?

\footnotetext{
${ }^{8}$ I do not have the space to make a fuller argument, but it seems to me that keeping categories "separate" or "pure" is never done in the abstract, but always in the messy, sticky materiality or objectivity of the world. It is only in material expression that categories become vulnerable to the polluting effects of other categories. By the same token, it is only in the messiness of material expression that categorical play (as in metaphor) offers disclosure of possibilities, a striving for otherness or nextness.
} 
1 But perhaps of most concern to religious authorities, were the integrity and "accuracy" of the Qur'anic recitation in the painting. From early on, Pirous was subject to their authority, and had to grapple with a normative custodial ethics for presenting Qur'anic verse. His paintings always present Qur'anic passages in full, legible calligraphic form, without blemish or flaw. Yet the material vulnerability of the paintings left him open to criticism. On several occasions, clerics saw in splashes of paint errant use of the diacritics needed for Arabic writing. On other occasions, the calli9 graphic figures-built up as they were in modeling paste-suffered chips raised complaint from religious authorities, and Pirous had to keep the paintings touched up and in good repair (George 2009, 2010).

The bundling and stickiness of material properties in Pirous's Qur'anic paintings may leave them vulnerable, but that same bundling and stickiness also matter to the aspirational character or intent of the works. By this I mean there is in (or behind) these paintings a striving to discipline, to work through, and to discover visual possibilities, surprises, and pleasures in the bundling and stickiness of the material. 9 This creative striving is not an aesthetic venture alone, but an ethical one as well. For example, one may discover goodness and ethical pleasure in using visual materials to praise or glorify God-the religious gesture known to Muslims as tasbih. The eye-catching radiance of gold leaf, the intensity of saturated colors, the texture of surfaces, and the harmony and proportionality of space and line, all serve the ethical aim of tasbih, adorning the Qur'anic message and glorifying God's magnificence. ${ }^{9}$ There is in Pirous's approach to the play of sticky, bundled materials a gesture of "good conduct" toward the divine message.

\section{Conscience Requires a Visual and Material World}

Pirous has always been happy to learn that someone felt pleasurably cool and calm in the presence of his paintings. This, I think, is one of the ethicoaffective aims of his work - to produce a pleasurable mindfulness of the divine by way of the gentle appeal or summons of a painting. If conscience is about dwelling with others in goodness, it seems to me that we might think about Pirous's paintings as "works of conscience" - they invite us to live, act, and see together in pursuing goodness and pleasure, perhaps even in pursuing "truth." That aspiration or aim, relying as it does on the stickiness and bundling of a painting's material properties in its striving, is always at risk

\footnotetext{
${ }^{9}$ Capturing or pointing to that divine magnificence without the use of Qur'anic calligraphy, says Pirous, is much harder that doing it with calligraphy. That is to say, without the bundling of "sticky" calligraphy, the ethico-aesthetic project of making a spiritual painting requires, in Pirous's view, far more work and creative vision.
} 
of being undone or derailed, or of being construed as an uncomfortable challenge to hierarchies of religious authority and value, on the one hand, and to the hierarchies and ideologies of artistic value, on the other.

There is no normative ethics for works of art with respect to their disclosures or affective aims. To take but another example from Indonesia's art world, there is the strident work of Arahmaiani, who aims to shock and critique the sensibilities of Muslim viewers and participants. In her performance of "Breaking Words," she wrote "Allah" on white ceramic plates in Arabic, invited audience members to write on them as well, and then smashed them against the wall. (Langenbach 2007). This iconoclastic gesture took advantage of the bundled material properties of ceramics and inks, as well as the stickiness of Arabic orthography, to shake participants loose from attachments that, in Arahmaiani's view, border on the fetishistic. For at least several viewers, the smashing of the plates was a humiliating and hurtful blow to God and to their affective attachments to God through material form. Complaints were lodged with the police. If Pirous's work aims at "ethical pleasure," perhaps we may say that Arahmaiani's strives for "ethical hurt" (not harm) or "ethical unease." Arahmaiani, too, is an artist of conscience, no less than Pirous. As Ahmed reminds us, "different people are made happy by different things [and so] object choices are not equivalent" $(2010,44)$. Ahmed goes on to "question what is appealing in the appeal to happiness" and does so with the purpose of keeping histories of injustice (done in the aura of happiness) from disappearing $(2010,50)$. Her aim is expose "unhappy effects," to reimagine what may count as the good life, and to find alternative models of the good in "those who are prepared to kill some forms of joy," even at the risk of living with the consequent unhappiness of others.

Allow me to push this essay to a close, then, despite my wish to linger further on the issues and arguments I have raised. A visual ethics is not so much about conveying ethical values supplied by this or that religion or this or that ideology in visual form, but rather, about pictorialmaterial space and substance as a site of ethical and affective encounter, aspiration, possibility, and dissent. Bundling and stickiness are the condition of that space and substance, and so seem to me a fundamental concern in the pursuit of ethical aims and direction. Conscience must contend with the bundled and the sticky even as it exploits them, disclosing itself to the world as it discloses a vision of one even better. ${ }^{10}$

${ }^{10}$ I owe special thanks to Charles Hallisey for coaxing me to think through my collaboration with Pirous with ethics in mind as I wrote Picturing Islam; to Anne Hansen for organizing an AAR panel on "Visual Ethics" as a symposium for the book; and to Elizabeth Bucar for pulling our essays together for this special focus in the Journal of Religious Ethics. I thank the three of them, and Richard Miller, for their encouragement and insights in the panel discussion. 
Ahmed, Sara
2006 Queer Phenomenology: Orientations, Objects, Others. Durham, N.C.: Duke University Press.
2010 "Happy Objects." In The Affect Theory Reader, edited by Melissa Gregg and Gregory J. Seigworth, 29-51. Durham, N.C.: Duke Uni- versity Press.

Arendt, Hannah

1958 The Human Condition. 2nd edition. Chicago: University of Chicago Press.

Bucar, Elizabeth

2016 "The Ethics of Visual Culture." Journal of Religious Ethics 44.1 (March): $\mathrm{xx}-\mathrm{xx}$.

Butler, Judith

2005 Giving an Account of Oneself. New York: Fordham University Press.

Das, Veena

2010 "Engaging the Life of the Other: Love and Everyday Life." See Lambek 2010, 376-99.

Flood, Finnbarr Barry

2002 "Between Cult and Culture: Bamiyan, Islamic Iconoclasm, and the Museum.” Art Bulletin 84.4 (December): 641-59.

Foucault, Michel

1997 Ethics: Subjectivity and Truth. Edited by Paul Rabinow. Translated by Robert Hurley. New York: The New Press.

Foucault, Michel

2005 The Hermeneutics of the Subject: Lectures at the Collège de France, 1981-1982. Edited by Frédéric Gros. Translated by Graham Burchell. New York: Picador.

George, Kenneth M.

2008 "Ethical Pleasure, Visual Dzikir, and Artistic Subjectivity in Contemporary Indonesia." Material Religion 4.2:172-93.

2009 "Ethics, Iconoclasm, and Qur'anic Art in Indonesia." Cultural Anthropology 24.4 (November): 589-621.

2010 Picturing Islam: Art and Ethics in a Muslim Lifeworld. Oxford: Wiley-Blackwell.

2012a "The Cultural Politics of Modern and Contemporary Islamic Art in Southeast Asia." In Modern and Contemporary Southeast Asian Art: An Anthology, edited by Nora A. Taylor and Boreth Ly, 53-68. Ithaca, N.Y.: SEAP Cornell.

2012b "Lifewriting and the Making of Companionable Objects: Reflections on Sunaryo's Titik Nadir." In Locating Life Stories: Beyond East-West Binaries in (Auto)Biographical Studies, edited by Maureen Perkins, 35-54. Honolulu, Hi.: University of Hawai'i Press. 
Keane, Webb

2006 "Subjects and Objects." See Tilley, Keane, Küchler, Rowlands, and Spyer 2006, 197-202.

2008 "On the Materiality of Religion." Material Religion 4.2 (July): 23031.

2010 "Minds, Surfaces, and Reason in the Anthropology of Ethics." See Lambek 2010, 64-83.

Kompridis, Nikolas

2006 Critique and Disclosure: Critical Theory between Past and Future. Cambridge, Mass.: MIT Press.

Lambek, Michael

2010a "Introduction." See Lambek 2010, 1-38.

2010b "Toward an Ethics of the Act." See Lambek 2010, 39-63.

Lambek, Michael, ed.

2010 Ordinary Ethics: Anthropology, Language, and Action. New York: Fordham University Press.

Langenbach, Ray, with Arahmaiani

2007 "Iconoclash." Broadsheet 36.3: 176-81.

Lynch, Gordon

2010 "Object Theory: Toward an Intersubjective, Mediated, and Dynamic Theory of Religion." In Religion and Material Culture: The Matter of Belief, edited by David Morgan, 40-54. New York: Routledge.

Mitchell, W. J. T.

2005 What Do Pictures Want? The Lives and Loves of Images. Chicago: University of Chicago Press.

Morgan, David

1998 Visual Piety: A History and Theory of Popular Religious Images. Berkeley, Calif.: University of California Press.

2005 The Sacred Gaze: Religious Visual Culture in Theory and Practice. Berkeley, Calif.: University of California Press.

2008 “The Materiality of Cultural Construction." Material Religion 4.2 (July): 228-29.

2010 "Materiality, Social Analysis, and the Study of Religions." In Religion and Material Culture: The Matter of Belief, edited by David Morgan, 55-74. New York: Routledge.

Pinney, Christopher

2006 "Four Types of Visual Culture." See Tilley, Keane, Küchler, Rowlands, and Spyer 2006, 131-44.

Povinelli, Elizabeth A.

2011 Economies of Abandonment: Social Belonging and Endurance in Late Liberalism. Durham. N.C.: Duke University Press.

Ricoeur, Paul

1992 Oneself as Another. Translated by Kathleen Blamey. Chicago: University of Chicago Press. 


\section{Simmel, Georg}

1950 The Sociology of Georg Simmel. Edited by Kurt H. Wolff. Glencoe, Ill.: The Free Press.

Tilley, Christopher, Webb Keane, Susanne Küchler, Mike Rowlands, and Patricia Spyer, eds.Handbook of Material Culture. Thousand Oaks, Calif.: Sage 2006 Publications.

Winnicott, D. W.

$8 \quad 1971 \quad$ Playing and Reality. London: Tavistock. 


\section{AUTHOR QUERY FORM}

Dear Author,

During the preparation of your manuscript for publication, the questions listed below have arisen. Please attend to these matters and return this form with your proof.

Many thanks for your assistance.

\begin{tabular}{|l|l|l|}
\hline $\begin{array}{l}\text { Query } \\
\text { References }\end{array}$ & Query & Remarks \\
\hline AQ1 & $\begin{array}{l}\text { Please confirm that given names (red) and surnames/family names } \\
\text { (green) have been identified correctly. }\end{array}$ & \\
\hline
\end{tabular}

